Cahiers d'études africaines

187-188|2007

Les femmes, le droit et la justice

\title{
Batswana Women and Law
}

Society, Education and Migration (c. 1840-c. 1980)

\section{Lily Mafela}

\section{OpenEdition}

\section{Journals}

Electronic version

URL: http://journals.openedition.org/etudesafricaines/7962

DOI: 10.4000/etudesafricaines.7962

ISSN: $1777-5353$

\section{Publisher}

Éditions de l'EHESS

\section{Printed version}

Date of publication: 15 December 2007

Number of pages: $523-566$

ISBN: 978-2-7132-2140-8

ISSN: 0008-0055

\section{Electronic reference}

Lily Mafela, «Batswana Women and Law », Cahiers d'études africaines [Online], 187-188 | 2007, Online since 15 December 2010, connection on 17 June 2020. URL : http://journals.openedition.org/ etudesafricaines/7962 ; DOI : https://doi.org/10.4000/etudesafricaines.7962

This text was automatically generated on 17 June 2020 .

(C) Cahiers d'Études africaines 


\title{
Batswana Women and Law
}

\author{
Society, Education and Migration (c. 1840-c. 1980)
}

\section{Lily Mafela}

1 Pre-colonial Tswana society, like many other comparable African societies was based on a strictly defined division of labour based on gender distinction. It was characterised by unequal power relations between men and women. In Tswana traditional society, men regulated women's social and legal sphere, and women were subjected to male control in many areas of their productive and reproductive lives. The age-old statement that "mosadi ke ngwana wa monna" ("a woman is a man's child") aptly captures this notion. Similarly, pre-colonial education served to perpetuate strict patriarchal control of women and domination over them by men. It consisted of informal and formal ways of socialization into the norms, traditions and practices of their communities (Schapera 1938, 1955; Comaroff 1985). This socialization mainly comprised behaviour modelling of adults by the youth, and formal initiation ceremonies, which were conducted at the youth's coming of age ${ }^{1}$. Patriarchal regulation of women's work and women's roles underwent fundamental changes during missionary and colonial periods, as a result of transformations that were unleashed onto the Tswana political economy and society (Schapera 1947, 1988; Schapera \& Roberts 1975). Education and migration were critical mediating processes to these changes. Moreover, in the changing circumstances, customary regulations and restrictions over women's lives and socio-economic status were irrevocably affected. The reduction of dikgosi $i^{2}$ powers in particular, was an important aspect of the transformation of Tswana socio-political structures. Hitherto, deriving largely from their political role under indirect rule policy, dikgosi were allowed to carry on exercising jurisdiction over all civil cases involving Africans ${ }^{3}$, while Roman-Dutch Law governed cases involving Europeans. It was also applied to cases that had no precedence in customary law (Molokomme 1990). The influence and interference of missionaries and the colonial government, brought about irrevocable changes to customary laws (Schapera 1955; Comaroff \& Comaroff 1991)4.

2 The introduction of general law into legal jurisdiction over Africans intensified during the colonial period, as the traditional institutions from which customary law emanated 
underwent gradual transformation. This went hand in hand with changes to precolonial socio-political institutions in general and to bogosi ${ }^{5}$ in particular. Bogosi was (as it continues to be) for all intents and purposes the repository of culture, and hence of (patriarchal) customary law $^{6}$. Transformations also came about as a result of the entrenchment of the cash economy generally. In particular, the colonial processes of trade, education and labour migration mediated, and added a further impetus to this development. This ultimately had a bearing on women's individual socio-economic and socio-legal status. To some extent colonial interference forced transformations to Tswana customary law, which benefited women, albeit it also left them vulnerable to the vicissitudes of a western ostensibly individualistic lifestyle.

3 The transformations which occurred in Tswana society have been studied by others, and resonate with those that occurred elsewhere in the continent, particularly with regard to Victorian ideological influences on missionary and colonial education (Morrow 1986; Kuster 1992). Women's education was always secondary to that of men and was primarily geared towards training women so that they would make suitable partners for the Christianised men. Women's education was ostensibly domestic oriented, in line with the roles that were envisaged for them. Colonial education of women also reflected these Victorian notions of women's place in the home and society. Women's vocations were articulated around what was regarded as their primary role as mothers, teachers and nurses ${ }^{7}$.

Patriarchy and Gender Ideology

4 This paper is informed by feminist modes of historical analysis. In particular it sets out from the premise that gender determines and underscores social relations of production in any given setting. This makes gender an important crosscutting issue in the study of current and historical (social) phenomena. The adoption of gender as a theoretical concept was partly catalyzed by the growth of feminist scholarship, as well as the women's rights movement, and gender activism generally. Lerner (1986: 239) conceptualised patriarchy as:

"The manifestation and institutionalization of male dominance over women and

children, and the extension of male dominance over women in society in general."

This definition recognises that women may not be completely robbed of power, influence and resources, but only that in general men hold power in all the important institutions of society and that women are robbed of such power (Lerner 1986: 239). The mode of analysis suggested here rejects the notion of separate spheres, and acknowledges the interactive relations between men and women. Gender is also used to "designate the social relations between the sexes, and [....] rejects biological explanations [....]" (Scott 1988: 32). Hence, gender is regarded as a variable and as a theoretical concept (Pessar \& Mahler 2001: 3). This study recognises that in their participation in pre-colonial and colonial processes, women were differentially positioned within the socio-political and economic structures of their communities. By the same token, their role in, and position within the socio-legal context was also mediated by their gender, as well as class. These were the main variables of distinction and engagement in Tswana society. Moreover, patriarchy ${ }^{8}$ was the common denominator for all these processes. It transcended all else and was the basis for regulating, shaping and organizing productive and social relations between men and women.

Aspects of Tswana Patriarchal Organization 
6 In pre-colonial times, Tswana women were enmeshed in a complex web of interpersonal and community roles and relationships, which were predicated upon their subordinated and subservient socio-legal position. Similarly to the situation elsewhere in the subcontinent, Tswana women's minority position ensured that in their productive and reproductive roles, women's activities were subject to patriarchal customary laws, rules and practices that upheld men's socio-legal dominance over them (Kinsman 1983; Stewart \& Armstrong 1990; Molokomme 1990).

7 The household unit was at the centre of Tswana socio-political and economic organization. It was interlinked symbolically and practically to wider political structures of the immediate kgotla $^{9}$, and through it, to the more central village kgotla. It was a place of political debate and decision making, which hinged upon a male- centred cosmology, in which the socio-legal position of women was strictly circumscribed. The household unit began undergoing changes, as a result of the effects of colonization, particularly due to migratory labour. Migrant labour transformed the Tswana household unit from a fundamentally patrilineal and patrifocal one to an ${ }^{10}$ increasingly matrilineal and matrifocal one, with attendant transformations to the productive and power relations between men and women.

8 Tswana organizational structure rested on a male-centred gender ideology, which was essentially patriarchal. In Tswana socio-political organization, one's lineal ancestors and descendants were traced through the male line, and settlement was patrilocal ${ }^{11}$. One's patriarchal relatives were the most important as they constituted a land-holding and cattle-owning group. One's uncle on the mother's side, that is, the mother's brother, stood in a special personal as well as productive relationship. For example, the uncle was the one who coaxed his niece into marriage and was responsible for "giving her away". Similarly, he was the one who received the symbolic bride wealth or cattle, and had the additional responsibility of arbitrating in marriage squabbles involving his niece, with the main aim of keeping the union intact.

9 In Tswana society, a woman was considered to be a minor in a general sense. In regard to a married couple, the husband, ideally following discussion with his wife, made important and elaborate family decisions. Customarily however, women submitted to men and in general, the men's decisions prevailed. Such decisions related to personal, productive and reproductive aspects of their daily lives. Men wielded disciplinary authority over their wives and children, and a man could beat his wife in the privacy of their own household (Kinsman 1983). Moreover, men were responsible for looking after, and provided for the daily needs of their wives and families. Unmarried women were generally cared for by their fathers, and by their brothers upon the death of their fathers; sons provided for their widowed mothers, and uncles were responsible for their unmarried sisters' children. However, the relationship of men to women was an essentially patronizing one. Their fathers, husbands and brothers generally dominated women. Although Batswana women as a class were neither unvalued nor unappreciated, unlike men they lacked access to crucial resources, which were required for acquisition of individual socio-economic status due to the patriarchal nature of their society ${ }^{12}$. This situation tended to negatively affect, and also dictated women's minority socio-legal position in many spheres of their productive and reproductive lives.

Pre-colonial Tswana Society and Gender Social Relations 
10 Pre-colonial Tswana society customs, rules and norms of behaviour regulated the productive and personal relationships between men and women. These gender power relations were maintained through traditional education of youth, and specifically through bojale and bogwera, traditional initiation institutions. Young men were gradually integrated into duties related to the political affairs of their society, and were taught things such as, respect for the kgosi and the institution of bogosi ${ }^{13}$. They were also socialized into assuming the responsibility of working "to strengthen their nation or morafe in every way" (Interview with Bome, Kanye 1991). Men in the kgotla held discussions and made decisions pertaining to the political life of the morafe. Each ward also constituted a kgotla where the men folk held meetings and discussions on their own ward matters. Women were denied access to the crucial loci of power, and to the seat of socio-political authority and control-the kgotla. The kgotla was the supreme law making and rule enforcing place of public debate. It was essentially a male preserve, in which women were not allowed even as litigants and they could not sue independently in court at the kgotla. Women "depended on the goodwill and sympathy of their male relatives for representation in matters of litigation" (Kinsman 1983: 51).

11 The preclusion of women from the kgotla and its processes essentially was tantamount to their preclusion from political discourse. Hence, women were subjected to laws and regulations to which they could not contribute to, influence or challenge. They were generally socialised not to speak unless spoken to, and were taught to keep away from the public discussions of men: they were to mind their work, "and leave mahuku ('words') to men" (ibid.: 49). In addition, linguistic imageries and subtle pressure entrenched the notion that women who had "maitseo", meaning manners or "tlotlo" meaning respect, did not intervene or interrupt when men were talking unless they were asked to do so.

The teaching of "tlotlo" to girls reflected the distinctly different and ostensibly subordinate position that women occupied vis- $a$-vis men, a position that was bound up with their role as mothers and household caretakers. An oral informant explained that:

“Girls were taught 'tlotlo ya bagolo' ('respect for elders') like boys. But girls were also taught things that were related to the upkeep of the household, and the elders would emphasize to the girl that, we are teaching you these things because in the future you will be a woman and you will be sent to another household, (you must know) there you are going to be owned (ruiwa) by your husband and your in-laws. You must show them the same respect (tlotlo) in the same way that you have been showing respect to your parents [...]" (Bome, Kanye, 1991).

Similarly, a newlywed woman was socialized to relate to her in-laws in the same way that she did to (those whom she related to as) her parents. Underlying the ideology of "tlotlo" training was the understanding that the married woman received "tlotlo" not automatically, but rather she earned it by behaving in accordance with the (customary) social perception of "ngwetsi ya Setswana", literally meaning a Tswana daughter-in-law. This perception was itself a subtle form of pressure (and social sanction) that was intended to ensure women's conformity with the "norm". The following text puts this assertion in a clearer perspective:

"A daughter-in-law was highly respected. Upon her betrothal, if she found that the household of her in-laws was not strong, she was the one who lifted it up and strengthened it (in her role) as the woman (mosadi) of that ward (kgotla). She was the one who also took it upon herself to turn the ward into a haven (botshabelo) for all. She was the one to whom everyone turned and trusted [...]. That way, she became the woman of that ward (mosadi wa kgotla eo), and she became the one in 
charge (molaodi) [...] charged with the responsibility of putting right everything that was wrong in the ward. If and when she did all these things, her in-laws respected and gave in to her [...] in this way (to be) a daughter in-law was a big thing." economic control that was exercised over women by a dominant male ideology. An individual's ability to gain influence, power, status and the capability to exercise command over his or her personal life was directly related to their socio-economic position. Pre-colonial Tswana society was not homogenous and had its own internal divisions, whereby a "group" denoted either one's gender, one's class, or one's ethnic affiliation. Gender criss- crossed, and was itself criss-crossed by other categories of social distinction. Thus, in spite of the general communalism of the pre-colonial Tswana economy, gender remained an important determinant of an individual's (and women's) access to resources. It also determined the extent to which the individual would gain or lack status. In that way, gender also determined individuals' socio-legal position.

17 In pre-colonial Tswana society, cattle ownership was almost exclusively a male preserve. Men were the ones who tended and herded, as well as inherited cattle. Conversely, in most Tswana societies, women had almost nothing to do with ownership, maintenance and upkeep of cattle. In fact, Tswana taboos served as an ideological means of keeping women away from livestock. During menstruation for instance, women were debarred from entering cattle kraals or walking through a flock of sheep or goats, lest they cause them to abort or die. Due to changes in customs and practices, in some families girls increasingly herded livestock, although cattle herding has remained largely a male preserve ${ }^{14}$.

18 Male relatives customarily presented gifts in cattle to young men when they returned from bogwera, but there was no complementary system for young women upon their return from bojale. Through the system of "go tshwaisa"15, sons were also able to accumulate herds even during their father's lifetime. Contrary to the assertion made by Guy (1990) that Batswana women could not own cattle, some women were given gifts of cattle through the system of "go tshwaisa" by their fathers, and when they got married they were allowed to take their cattle to their husband's household. Such cattle served as a form of dowry and were referred to as "keteetso" 16 amongst Bakwena or "serotwana" ${ }^{17}$ amongst Bakgatla (Radijeng 2004). However, unlike their male counterparts, women did not have control over the disposal of their own cattle and they sought a man's permission to either sell or barter the cattle. The men were also responsible for herding and tending the cattle and customarily, they also carried out cattle transactions. 
19 The inheritance law particularly, highlights the social control mechanisms that were employed in Tswana society to keep women's economic and personal well being subservient to, and dependent upon their fathers, uncles, brothers, and husbands. A man's sons inherited his property upon his death. If he had been a polygamist, his eldest son by his first wife succeeded him as the head of the household and inherited its property, including cattle. The eldest son was appointed to look after both his inherited herd and that of his younger siblings. For this reason, he was euphemistically referred to as "mojaboswa" (literally, the eater of the inheritance, or the one who eats the inheritance). Part of a man's property would be distributed amongst his various wives and their children, but cattle were still the prerogative of the male siblings, while girls only inherited household utensils.

20 Men controlled land distribution, products of hunting, such as hides and skins, ostrich feathers and karosses. These became valuable commodities of trade with white traders starting in eh early $19^{\text {th }}$ century (Chirenje 1977: 256). Women's access to ploughing fields was mediated by their fathers or husbands control over the disposition of the grounds, through which they held usufruct rights (Kinsman 1983: 42; Schapera 1943). Generally, patterns of land ownership and property rights granted individual men quite different positions in community life from women. In contrast, women were cast into largely communal forms of ownership, which locked them into a situation of dependence and lifelong subordination (Kinsman 1983: 40). Hence, whilst women's activities were generally confined to strictly delineated spheres of the home and masimo or ploughing fields, men's productive occupations were easily and readily converted into value-added goods, such as exchanging products of hunting for precious commodities such as copper (Kinsman 1983).

21 At customary law, social sanction was the most pervasive and enduring of these regulatory processes. This was particularly so because customary law operated in such a manner that women would not protest against it-in the home and within the (smaller) kgotla or ward. The ward was more intimately linked to the household, and through it, decisions reached at the level of the more central kgotla filtered down to the household level (Schapera 1970). To a large extent, Tswana traditional/customary law was inherently patriarchal, and in this way, it governed and regulated all facets of women's lives, through layers of traditional institutions and structures. The household unit was the locus of women's socio-legal restriction, as laws and regulations were relayed through and into it. Patriarchy operated through societal and community sanction, as well, through the practice of ostracising those who did not conform to the established norms and codes of behaviour. By the same token, women did not have access to socio-legal structures, and generally relied on their fathers, husbands, uncles and (adult) sons for representation in matters of litigation (Schapera 1938, 1955; Kinsman 1983: 51; Molokomme 1990; Radijeng 2004). Thus, the Tswana patriarchal structures comprehensively and effectively excluded women from a crucial means of gaining socio-economic status.

22 Although pre-colonial Tswana socio-economic structures depicted a sharp division of labour, men's and women's work did not strictly conform to the Western public/ private trajectories. Thus, the homestead as the Tswana unit of production was more widely encompassing than the western notion of "household". It encompassed both the "masimo" ("ploughing fields or lands") and the bush or forest. During contact with missionaries and formal colonization, some notions of Tswana womanhood and 
woman's work were changed while others were reinforced. Generally, Tswana socioeconomic and political structures underwent significant transformations during the colonial period (Schapera 1936, 1947, 1988; Schapera \& Roberts 1975; Comaroff \& Comaroff 1991, 1992).

Missionaries, Western Education and Socio-Economic Transformation

The first recorded contact between Batswana and Europeans occurred at the turn of the $19^{\text {th }}$ century, when the early travellers, traders and missionaries began to work amongst Batlhaping and Barolong, who resided to the south of the land that was later annexed as Bechuanaland Protectorate (Chirenje 1977). The London Missionary Society (LMS) was the first mission to work amongst Batswana of present-day Botswana ${ }^{18}$. In 1845, David Livingstone of the London Missionary Society commenced work among Bakwena who were then living a Chonwane, and moved with them to Kolobeng in 1847. The LMS monopolised work among Batswana until the arrival of the German Hermannsburg Missionary Society in 1857 (ibid.: 70). Others such as the Dutch Reformed Church, the Roman Catholic Mission and the Anglican Churches made their entry from around 1875 onwards (Colclough \& McCarthy 1980: 205).

In order to facilitate their primary mission, early on the LMS missionaries established seminaries for training of evangelists, which served as a foundation for more concerted evangelization and educational efforts. The basic mission work comprised preaching the bible and conversion of Batswana into Christianity. However, in addition to proselytising, missionaries began to provide the rudiments of literacy. Thus, evangelists essentially functioned also functioned as "out-reach" teachers as well (Richardson 1899). Amongst Batswana, missionaries were primarily responsible for provision of education to Batswana for most of the colonial period, in exception of educational efforts of Batswana themselves (Mafela 1993). The colonial government only started providing financial assistance in the form of minimal grants-in-aid in $1904^{19}$. This however comprised a small proportion of the total educational expenditure incurred by missionary bodies. As western education took root, and as its benefits became apparent, dikgosi imposed additional levies to fund their own "independent" educational efforts, either to augment or to sideline those of missionaries when it suited their needs ${ }^{20}$.

The commercial arm of missionary labour ensured that the London Missionary Society station of Kuruman became famous not only for literacy and agricultural technological developments ${ }^{21}$, but for commercial trading as well. Hence, trade and commerce were crucial accompaniments to missionary labour. Inadvertently, western laws and practices regulated the context within which trade operated. Moreover, the changed world views which came about as a result of a changed lifestyle occasioned by the spread of religion, trade and commerce had important repercussions for men's and women's socio-legal status. This was so particularly because men were the ones who were generally engaged in commercial activity. This created wider divisions between men and women, as men gained greater access to resources, and the attendant socioeconomic upper hand over their womenfolk. This process was later mediated by others which were occurring in the wider socio-economic sphere, particularly colonial education, as well as migration for both education and employment.

At the time of colonization, missionary and trader activity had deeply entrenched the cash economy into indigenous socio-economic structures. These activities had also begun to shake the foundations of Batswana spiritual and physical orientation of their 
world-views, which reflected the beginnings of a western livelihood, which transformed their socio-economic, political and personal lives. A clear system of western education was also in place. From the crude beginnings of early bible classes there gradually developed a more systematic schooling system of schooling. There were a number of mission schools mainly amongst Bakwena, Bangwaketse and Bangwato which offered some academic education alongside religious teaching (Mafela 1993: 132). The Shoshong Seminary, and the Kuruman and Moffat Institutes were established specifically to train evangelists who also doubled up as schools teachers. Industrial training was incorporated amongst the subjects taught at these institutions. Girls' formal education, which focused on domestic education, was first offered at the Moffat Institute in 1882 (ibid.). It was consolidated at Tiger Kloof when the Institution started admitting girls in $1916^{22}$. Initially, the primary role of women's education was to train and provide good Christian wives and mothers to provide suitable partnership to newly Christianised men ${ }^{23}$.

Missionary and colonial education reflected Victorian-based notions of gender, which reflected the woman's role, as it had it evolved in $19^{\text {th }}$ Century industrialising Europe. In the missionaries' own society, the role of the woman in the home was crucial to the creation of a particular moral order, which served the larger needs of discipline and social control. In the colonies, missionaries and colonial officials sought a cultural ordering of African society by "creating new forms of male work and female work". They sought to reshape "African notions of labour and time, architecture, consumption and accumulation, body and clothing, diet and hygiene [...] and to impose western notions of household organization and gender on local conceptualizations [...]" (Comaroff \& Comaroff 1992: 39).

Hence, the role of the African woman, especially in the home, was crucial to the sociocultural reorganization of Tswana society. This was partially addressed through provision of western education. Missionaries particularly directed their relentless efforts at substituting, by a European Christian value-system, aspects of Tswana society, which they regarded as "heathen" and abhorrent from a Christian standpoint. In converting Batswana to a western value-system, missionaries launched specific targets at those customs of Batswana, which they regarded as prodigious impediments to the spread of the gospel. The most worrying to missionaries were the initiation rituals and polygamous marriages. Missionaries especially regarded polygamy, which was based on the homestead as the basic unit of production, as an impediment to the individualistic, rational, capitalistic ideal. In Botswana and in other parts of Africa, missionaries questioned and criticised the institution of bogadi, a pivotal institution for women's appendage to men for many aspects of their lives.

Through missionaries' spiritual evangelization, religious conversion and persuasion of Batswana converts, missionaries managed to bring about transformations to the Tswana way of life and to the customs traditions, rules, practices and laws. The shifts in spiritual identity and commitment went hand in hand with the recognition that, their conversion (reciprocally) inhered in the quotidian practices of the "civilising mission". Through their conversion and their practices of the new religion, the newly converted appropriated a new consciousness, albeit eclectic, which rested on questioning and gradually discarding some traditional rules and customs, in which were embedded customary legal codes. In this regard, Comaroff and Comaroff (1991) observe that:

"Those [...] drawn into the church soon realised that they had to accept, in no small measure, its methodical, rule-governed ${ }^{24}$ regime: to be seen to adopt, that is, the 
conventions of sekgoa ${ }^{25}$. 'Interested inquirers' who wished to drink at the fountains of the LMS and WMMS-to cultivate their irrigated fields, use their tools, learn to read their books, rely on them as a defensive shield-were expected to acknowledge their beliefs and assent to their "laws"' (Comaroff \& Comaroff 1991: 246). the unintended effect of easing women's socio-legal burden. In a similar vein, Gugler (1972) observed that:

"Western ideology has been a potent factor in changing the position of women in much of Sub-Saharan Africa: most Christian missions propounded a doctrine of the equality of marriage partners; schools taught boys and girls; print, radio, and screen extolled the overriding importance of love [...]" (Gugler 1972).

31 colonies across many parts of the continent (Jeater 1993b).

32

Trade and commerce were important auxiliaries to the religious educational endeavours. They were a most potent expression of the individualism of the protestant ethic that was central to the mission agenda ${ }^{26}$. The slogan "civilization through commerce" became the cornerstone of missionary evangelizing endeavours. It reflected the spirit of capitalism espoused in the Protestant ethic, while at the same time seeking to provide a "Christian alternative to what was regarded as impediments to commercial capitalist enterprise". Missionaries encouraged cash crop farming, as well as supplying "suitable mechanical and agricultural implements". The introduction of the plough greatly revolutionized agriculture, and by 1895 , there were reportedly about 1,500 ploughs amongst Bangwato alone (Parsons 1977: 49). The introduction of the plough into Tswana society resulted in the re-structuring of the existing social relations of production. Possibly due to their own patriarchal prejudice and background, missionaries introduced only men to the plough and the new farming methods in the mission station. This was so in spite of the fact that Batswana women were hitherto the principal agricultural workers. In the new cash economy, men were able to accrue significant monetary gains from the sale of agricultural produce. Reportedly in the late 1830's, "people (men) made rapid advances in civilization; some purchasing wagons, and breaking in their oxen for those labours which formerly devolved on the female sex". This process further galvanized efforts by Batswana men to acquire of individual socio-economic status that remained largely out of women's reach $^{27}$.

Batswana initially became involved in labour migration in order to buy firearms, which dikgosi required for protection mainly against Boer incursions, as well as against other Batswana groups ${ }^{28}$. Thus, Batswana began migrating to the mines as early as the 1870 's with the first discovery of diamonds at Kimberly, followed by gold at Witwatersrand in 1886. But while Batswana originally migrated from a position of strength, they were later to do so generally from a position of weakness (Bozzoli 1991). For example, in 1880, Kgosi Linchwe of Bakgatla sent a regiment to work in the Kimberly mines to raise money to buy ammunition to be used in the war against Bakwena. As alluded above, during the colonial period, Batswana increasingly migrated mainly in response to colonial exigencies, such as taxation and generally due to their overall integration into the South African cash economy. Labour migration permeated the socio- economic milieu to the extent that it came to be widely regarded as a kind of a rite of passage, and as a form of initiation into manhood (Schapera 1947: 118). This became so, particularly because it was bound up with the responsibility of paying taxes, and all 
youth going out to the mines were automatically registered for payment of tax (ibid.: 116). However due to other developments, which resulted from the entrenchment of the cash economy, and partly fuelled by changed lifestyles, dikgosi also started sending men to the South African mines to earn money for community purposes, as well. It was colonization however, which fuelled labour migration to unprecedented levels, where it remained throughout the colonial period.

The land of Batswana was declared a protectorate in 1885, when it was renamed the Bechuanaland Protectorate ${ }^{29}$. Following colonization, the British did very little by way of administration ${ }^{30}$ and adopted indirect rule policy, through which they allowed dikgosi to continue ruling over their own people (Lugard 1922; Hailey 1953). Bechuanaland was expected to pay the cost of its own administration, to ensure that it did not become a burden to the British taxpayer. Hut tax was introduced in 1899 in order to raise the required revenue to meet costs associated with security, particularly the upkeep of the security organ, the Bechuanaland Border Policy. From 1899 until the time of independence, hut tax was the major means of raising revenue for Bechuanaland Protectorate (Maylam 1980: 216). At the time of colonization, Bechuanaland was divided up into the customary tribal reserves and Crown lands, the former consisting of dry, arid land, whilst the latter consisted of areas that were more conducive for crop farming and cattle ranching. These colonial exigencies comprising taxation, land alienation added to the economic hardship already faced by the populace in the form of famine, cattle diseases and recurrent droughts. The situation was made worse by the fact that Bechuanaland Protectorate had very few economic concerns, and there was very little economic activity for most of the colonial period ${ }^{31}$. This exacerbated its economic situation as a South African labour reserve (Kowet 1978; Colclough \& McCarthy 1980). However, Batswana socio-cultural connections with South Africa also played a role in enabling cross-border migration for education and forms of employment other than mine work ${ }^{32}$.

There were other opportunities created by the mining boom, which facilitated further development and entrenchment of the cash economy amongst Batswana. The mining boom created markets, which afforded Batswana men the opportunity to sell their grain to the Kimberly and Rand gold mines. Between 1889-1894, the amount of grain sold to white traders at the Bangwato capital of Phalapye was around 1,000 bags. Some Batswana farmers were able to amass enough profits to buy wagons to carry their wares to the market. Wood cutting and transporting also became a profitable venture in the diamond and gold mines. The construction of the railway line, which passed through Bechuanaland in 1896, facilitated this trade boom (Parsons 1977). In addition to facilitating communication and transportation, the telegraph and railway lines created significant employment opportunities for Batswana men. Male labour was recruited from the Barolong farms area right up to Phalapye ${ }^{33}$.

Although labour migration was primarily fuelled by the need to raise money to pay hut tax, other reasons sustained it, such as the changing lifestyles of people. Their increasing reliance on new items of daily use resulted from an evolving worldview, and a new consciousness, and an interpretation of their place in the colonial state. This consciousness reflected the totality of processes through which Batswana socioeconomic and political structures were gradually transformed. By the 1920's it was apparent that the spiritual, educational and commercial processes, which were set in motion by missionary and trader activity were the main drivers for labour migration of 
Batswana. In 1933, it was noted that "the exodus of Natives is having a terrible effect on the territories" (Pim 1933 in Schapera 1947: 43). Whilst Batswana were initially compelled to migrate for employment purposes, they were increasingly engaging in "voluntary" or "independent" labour migration (Maylam 1980: 217; Torrance 1998). By the 1930's labour migration had become a regular form of earning money for livelihood, rather than for a specific purpose such as taxation (Shapera 1936: 237). People also tended to opt more for labour migration and away from pastoralism and subsistence farming as a means of livelihood (Pim 1933). As time went on, "the growing impoverishment of their territory and the ubiquitous presence of labour recruiters, aided by collaborating dikgosi and administers, undermined the capacity of Batswana for self-sustaining independent production and drove them more and more into the South African labour markets" (Maylam 1980: 217). Perhaps the situation can best be summed by one elderly man's nostalgic recollection that:

"It was happening during our times, when times had changed. There were very few places to sell things, and we were merely cultivating for consumption (go ja). We herded cattle, and raised them merely for their meat. We ate the meat, as there was nowhere to sell cattle or grain. And that is why we used to leave these things behind to go where money could be found. There was a need for money, as things kept changing [...]. Even females (of maybe your age and under) [...] we were all being used (jewa maraga) by the Transvaal [...] (You) females were going to the corn fields to harvest corn, so that you could get hold of money, leaving your own household's corn unattended, getting destroyed by pests, because you had nowhere to sell it [...]" (Bome, Kanye, 1991, extracted from Mafela 1993: 103).

The "need for money" mentioned above signified the extent to which the Tswana precolonial economic structures were transformed and peripherally integrated into and their peripheral integration into the capitalist economy. Like other Southern African communities, they were gradually incorporated into the Southern African economy, as a labour reserve. Due to this, the District Commissioner comment in 1935 that:

“[...] Were it not for the Union market for our Native labour, the government would long ago have ceased to collect tax, the traders would have gone out of business, and the Natives [...] would be depending more than ever on Providence." goods, which migrants purchased and ferried when they returned home (Schapera 1947). In 1947 it was estimated that $47 \%$ of the total cash income of "the native population is derived from employment in the Union (South Africa)" (ibid.: 179). Most of the men who migrated were in the able-bodied groups (15-44). Generally, the rate of labour migration rose from a few hundred at the beginning of the 20th century to 50,000 by the 1960 's (Colclough \& McCarthy 1980).

As previously noted, education also increasingly facilitated adoption of new lifestyles, as the need grew for goods, which conformed to the emerging socio-economic milieu. Adoption of a new lifestyle became even more pronounced amongst the educated sections of the society, a significant number of which were Christians and well to do as well. Although labour migration was not confined to the poor, or to those with little or no education, it was more prevalent among the poorer sections of the society. Nonetheless, both education and migration became important drivers of change in the people's way of life and changing value- system, particularly with regard to youth-both men and women (Schapera 1947: 168). transformed the Tswana way of life more intensively, because the western educated 
Batswana more readily "copied western ways of life" whereas migrants were only concerned with purchasing various items without necessarily emulating European lifestyles (Schapera 1947). This analysis was probably directed primarily at men's migration, however. This is because for women, the effect of the freedom which migration and (and unfettered) mobility granted was undoubtedly far-reaching. Rather, it may well have been that in terms of education, and women's participation in it, Batswana were less worried because schools, even those which were outside their geographical locations were subject to strict regulation. It is important to note that even in regard to educational mobility or migration, traditional authorities maintained firm control, and women were not allowed to travel alone. One informant related how for example, on the long journey from Serowe in Botswana to Tiger Kloof, they were always accompanied by bigger boys who were specially appointed by Kgosi Khama ${ }^{34}$.

Thus mission and colonial "civilising" influences which led to development of new needs and wants, equally contributed to labour migration (Moffat 1842). This was mediated by another phenomenon: Batswana perception of education as a means to securing cash. Thus, beginning in the early part of the $20^{\text {th }}$ century, Batswana expectations of the benefits associated with education underwent transformation. Although Bechuanaland Protectorate itself was severely underdeveloped both educationally and economically, the incorporation of Bechuanaland into the South African administrative system expanded both the educational and employment market for Batswana ${ }^{35}$. Hence, there was considerable cross border migration for educational purposes as well, which ran parallel to migration for employment.

Western education played an important role as the method by which western ideals were entrenched. As an ideological tool, it served the needs of the mission and those of the colonial enterprise. Colonial education policy was essentially congruent with the basic principles of western education and commerce, as reflected in earlier missiontrade work. British colonial rule encouraged and supported mission work, although financial support remained negligible ${ }^{36}$. Amongst Batswana, education was primarily left in the hands of missionaries up to independence time. It was only augmented by the "independent" educational efforts of Batswana themselves ${ }^{37}$. Batswana remained heavily reliant on missionary institutions throughout the colonial period, and minimal grants in aid barely eased the missionary burden of educating Batswana. Hence what could be accomplished remained negligible, particularly in terms of providing postprimary education ${ }^{38}$.

Domestic education was particularly crucial to the entrenchment of colonial rule, but its emphasis and direction were mediated by and mirrored other changes occurring in the wider political economy. Colonial education policy reflected the needs of government at a particular time, and the largely middle-class background of the colonial civil service helped [to] shape domesticity through its policies [...] either in collusion or in conflict with local white residents or rural African authorities. In particular, domestic education and training had a crucial role to play both in the spread of Christianity and in "propping up" colonialism. Although missionaries and colonial officials had similar notions of womanhood, domestic training of women served different purposes for each, and in each case, it did not necessarily or always sit well with the interests of African males. Thus, in Africa generally, gender redefinitions that were engendered led to tensions, frictions as well as opposition. For example, in Buganda "the chiefs [...] insisted that cultivation and home management be central to 
the school's curriculum (and) agreed to girls' education only after they were assured it would not take girls away from domestic roles" (Musisi 1992) mongst Batswana also, girls' education was not always accepted and even where it was, the acceptance was gradual and remained subject to the other needs, rules, customs and general restrictions of Tswana society. For example, although Kgosi Khama sent his daughter Bonyerile to school in South Africa, he promptly withdrew her from school and married her to his newly appointed headman, Lekhutile. The changing educational aspirations of women also led to tensions in personal relations between men and women, where Batswana sometimes held ideas that conflicted with those of missionaries over the education of their daughters. In general, and due to economic necessity, girls' education was more readily sacrificed than that of boys (Van Hook 1994: 296) ${ }^{39}$.

Missionary and colonial educational developments, which traversed British Tropical Africa, resonated on the Victorian nature of the values, which informed the curricula taught in many colonies ${ }^{40}$. In South Africa, institutions such as the co-educational Lovedale Institution offered a gender-biased educational menu, whilst the Inanda Seminary was a Girls Boarding School, which offered a "coveted" type of girls' domestic-oriented education and training for daughters of colonial Black elites, who were sent there from as far as Zimbabwe and Uganda, as well as from different parts of South Africa itself (Kuster 1992: 179). In Uganda, Gayaza Girls'Boarding School operated along similar lines to Lovedale, similarly with the Mbereshi Girls' Boarding School in the present-day Luapula Province of Zambia ${ }^{41}$.

As was the case elsewhere in British dependencies, colonial education was strictly gender-specific and was targeted to transform the role of Tswana women in conformity with missionaries "proselytizing" and "civilizing" objectives. Although women were not debarred from attending formal bible classes [which in fact they attended in larger numbers than men], the missionaries' actual target for women's education was training in housework. In missionary terms, such work ostensibly excluded agriculture, which missionaries felt contravened the Victorian domestic ideal. Just as formal and informal Tswana initiation rituals and socialization methods had lent "womanhood" its institutional efficacy through the traditional initiation institutions of bogwera for boys and bojale for girls, the move towards formal institutionalization of domesticity began with the teaching of rudiments of sewing, knitting and cookery, while boys were taught woodwork, and agriculture. Missionary education stretches as far back as the beginning of missionary work amongst Batswana, since it evolved as teaching of basic literacy to enable people to read and understand the bible, as well as to write simple sentences.

In many ways, western education was a potent change agent in that, as it evolved it integrated gender specific industrial education. Industrial education was ostensibly used to inculcate the spirit of self-reliance in producing simple implements and furniture for the home. These were aligned to the emerging western lifestyle in indigenous communities. This approach to mission work laid the foundation for (formal) industrial training in missionary and colonial institutions across the subcontinent ${ }^{42}$. From the late $19^{\text {th }}$ century to the early part of the $20^{\text {th }}$ century, industrial education featured prominently in the curriculum, and was directed at "teaching simple habits of industry" (Chirenje 1977). Industrial education policy was also aligned to the wider needs of the colonial enterprise, in which Africans participated as semiskilled labourers in the various European concerns, as more specialised vocations were reserved for Europeans. 
In the early 1900's, industrial education began to lose its earlier appeal to Batswana because their perceptions about the benefits of schooling had changed, in response to the changing socio-economic discourse. They increasingly demanded more and more "academic" education, due largely to the fact that there were many avenues opening up for jobs as interpreters, secretaries and clerical staff for missionaries, dikgosi, and colonial government officials. English was specifically desired, due to its role in the unfolding socio-economic milieu. In 1908 it was observed that:

"The first impulse of the recently Christianised Natives who send their children to school is the exact reverse of a desire for the more perfect command of their own language, whether spoken or written. The less the idiom is taught and the more rapidly English is introduced, the better they are pleased" (Sargant 1908, quoted in Chirenje 1977: 184) ${ }^{43}$.

Batswana perceptions of education continued to influence curricula offering and generally shaped educational endeavours from this time onwards. Moreover, from the late 1920's, colonial education of Batswana came under the influence of the continent wide developments arising from the reports of the Phelps Stokes-funded African Education Commissions. The Commissions were conducted in 1922 and 1924 respectively, and came to influence African colonial education policy from the late 1920 's and 1930's. The work of the Commissions directly influenced the "adapted" Phelps-Stokeist Jeanes- oriented ${ }^{44}$ educational activities ${ }^{45}$. Adoption of the recommendations of the reports resulted in the reorientation of colonial education policy towards "ruralisation" and "peasantization" (King 1971; Bude 1983) ${ }^{46}$. This was reflected in the type of educational policy adopted and the broader ideology that influenced it, which sought to align education more closely with the rural economy. Men and women were necessarily educated to occupy different positions within the rurally-based colonial economy. This was in direct contradiction to the views not only of Batswana, but other Africans at this time, and the demand of an increasingly academic education.

In Bechuanaland Protectorate, the Jeanes-type of training for boys was offered at the Khale Handyman and Agricultural Institution. This institution however failed almost immediately, due to its strong leaning towards manual labour (Mafela 1993) ${ }^{47}$. Conversely, although Tiger Kloof had been established earlier as an institution which also offered industrial training, the variety of its educational menu, and its growth as an "elitist" institution ${ }^{48}$, helped to gain it acceptance and success. Hence, Tiger Kloof remained popular with Batswana, even though it was located outside their own territory.

The Jeanes-type of education policy did not depart fundamentally from earlier conceptualization of women's education. Essentially, it still reflected the genderspecific nature of colonial curricula and still emphasised strong linkages of women to the domestic and the home-bound and care-giving vocations. In regard to the Jeanestype training for women, the Dutch Reformed Mission established a domestic training school for young women at Mochudi in 1943. Although the establishment of the Mochudi Homecraft Centre was couched in the "Jeanes" discourse, it evolved as an institution offering a "superior" type of domestic education ${ }^{49}$. This increasingly earned it a good reputation among Batswana, as a school training "makgoanyana" ${ }^{50}$. It also received international accolades and hosted many international visitors (Mafela 1994). Its products had many avenues for employment and "enviable" engagements in society. Some became domestic science teachers, others worked as housekeepers in homes of 
high ranking civil servants who were almost exclusively white. Hence, the process gradually opened the way for more and more women to venture into the employment sphere. Hence, from the 1940's onwards, domestic education was no longer desired or studied for its "domesticating" effects alone, though it was still a desirable and effective means of transmitting the values and symbols, which were an important mark of "civilization". More increasingly, it was also seen as a viable economic option, especially due to the limited employment opportunities in Bechuanaland ${ }^{51}$. Generally those who could afford it increasingly sent their children to schools outside the country, mainly to South Africa and Southern Rhodesia to access similar institutions ${ }^{52}$.

51 Thus, as many parents realised the benefits of girls' education, as a means to employment and an improved livelihood-in conformity with prevailing notions of what it meant to have a better life-they gradually relented. Consequently, more women were also able to participate in schooling, a few even managing to go into post-elementary schooling. They also began to venture into training and employment as teachers, albeit confined to the care giving and domestically inclined vocations, such as nursing, primary school teaching, and secretarial work. Importantly too, this state of affairs signalled the growth of women's entry and participation in the labour market. Along with this development, was the gradual acceptance of women as "mobile" workers, and increasingly, avenues opened up for women's employment as teachers ${ }^{53}$.

Although Victorian missionary education enabled women to venture into wage labour on a higher scale, in some ways the missionary and colonial cosmology reflected, as well as converged with some of the patriarchal notions that under-girded pre-colonial (customary) restrictions on women. For example, notions of "head of household" and "breadwinner" resonated with Victorian notions of "kept women", and hence perpetually requiring men's protection and support ${ }^{54}$. There were also ways in which the male- dominated socio-legal ideology of the missionaries' own society, and the Tswana traditional one generally converged to limit the scope of women's opportunities in both education and employment. The regulations governing women's participation in employment were generally informed by the Victorian moral ideology, which ostracised unmarried women who fell pregnant. Unmarried female teachers who fell pregnant were also discriminated upon. In this way, many Batswana women were initially denied access to higher schooling and meaningful participation in wage labour (Vanqa 1998) ${ }^{55}$.

53 Education as a colonial sphere of engagement was also linked to issues of migration in other ways, as well. This is because education provided women with the first opportunity to move outside the household and into other spheres of activity. It enabled women to move out of the strictly controlled education space-the school-in the first instance, and increasingly for employment. Since educational facilities were not spread out in the country, many of those who wished to access schools had to leave their villages to access schools in other areas. It was even more imperative for those who sought higher education ${ }^{56}$, as they had to travel to schools outside the country, mainly to South Africa. This type of "migration" for purposes of schooling cannot be divorced from the process and evolution of economic migration for employment purposes. In fact it can be safely stated that educational migrants constituted the first types of organized migrants from Botswana mainly to South African institutions, and to a lesser extent to Southern Rhodesian institutions as well ${ }^{57}$. 
While educational migration was closely controlled, labour migration was unregulated. This compelled dikgosi "traditional" authorities to embark on strategies to regulate female labour. Female labour was mainly clandestine, and hence it proved harder to control, in contrast to male (mine), which was secured through the use of recognized labour agents ${ }^{58}$.

Generally, Labour migration accorded its participants the freedom from customary obligations, as they spent a lot of time away from the clutches of chiefly and family control. This phenomenon meant for example that male and female youth were no longer beholden to parental control in terms of sanction on their general behaviour, and on marriage arrangements in particular (Schapera 1947). Migration also adversely affected the agriculturally-driven homestead economy, due to the inherent absence of able-bodied men. As a result of these concerns, dikgosi tried in vain to curb migration, even going as far as to engage the colonial government to help ${ }^{59}$. The system of contracts partly ameliorated the situation, although it was not primarily intended to serve dikgosi's objectives, but rather it was done in conformity with the seasonality of farm work in the white economic concerns. This also accorded mine labour migrants periods of rest. Oscillatory labour also served well the needs of capital, since the rural home base also served the reproductive needs of capital. The system of contracts though it did not significantly curb migration appeased dikgosi because it reduced the phenomenon of bokgwelwa (desertion) since it compelled men to return home and to provide for their families, as well. As these changes became more pronounced, dikgosi sought to minimise its effect by placing controls over it, such as measures that would enable ease of tracing migrants. This also served to improve the security of migrants abroad. Nonetheless these measures did little to curb migration, particularly that many migrants particularly women were not "official" migrants and so could not be captured by the system.

Increasingly, dikgosi's efforts to curb migration were more specifically targeted towards female migration. The need by dikgosi to limit women's mobility was linked to the need to control their sexuality, in line with the role played by women in the homestead economy and women's envisaged role in it.

Women as Migrants: Customary Legislation and Pass Laws

Indeed, while labour migration proved to be such an indispensable form of livelihood for Batswana, it would seem that originally, it was mostly Batswana men who participated, while women remained in the rural areas where they continued to provide the men's productive and reproductive needs. Increasingly however, women also engaged in migration independently of men, although to a lesser extent than men. However, their migration possibly started long before they were recognised as such. Employment migration enabled women to get out of the restrictive homestead, away from male control and constant customary sanction over their lives. Migrating women comprised mainly single young women, divorced, abandoned and widowed women. They were generally able to earn an independent source of livelihood, and this enabled them to have a measure of control over their lives. Hence, Batswana dikgosi increased their efforts mainly towards sanctioning women's migration, particularly that of young women, in order to curtail their independence from male control.

Generally, women were employed on South African farms for cotton, oranges and vegetable, as well as domestic workers in white households and in factories (Marks \& Unterhalter 1978; Brown 1983). They were employed in both the urban and rural parts

Cahiers d'études africaines, 187-188 | 2007 
of South Africa, particularly in the Witwatersrand and in the Transvaal areas of Zebediela (citrus farm), Rustenburg (tobacco and cotton plantations), Magaliesburg, Mafeking, while men went as far away as Natal quarry (Schapera 1947; Interview with Motshabi 1990). A number of women were also engaged in petty trading activity, such as prostitution and "illicit" beer brewing, as well. But men also participated in petty commodity distributive trade in places like Mafeking and Zeerust (Shapera 1947). Migrants, both men and women from Bangwato and Tati Reserves and also went to Southern Rhodesia ${ }^{60}$. This was due mainly to the ease of access provided by the close proximity of these areas to Southern Rhodesia. Otherwise, this destination was generally less attractive than Mafeking and the Transvaal (in South Africa) for most migrants.

59 There was a tendency of younger women to migrate more extensively than their seniors. This was particularly so with regard to unmarried women (Schapera 1947: 66-67). This was a significant departure with customary practice, whereby under customary law, whatever their age, were always subject to the authority of their father or a male relative. In essence if followed to the letter such women would not have been able to lead independent lives, as it was now possible for them to do in the receiving areas. Widowed women also formed another proportion of those who were migrating, and were seemingly doing so in increasing numbers. This also denoted a departure with customary law that required widows to be placed under the guardianship of their late husbands' brothers or their eldest sons ${ }^{61}$.

60 Female migration was inhibited by and hence subjected to customary laws and sanction and "tribal" authority. For the women (and young women in particular), migration assured them a degree of freedom not possible at home, and accorded them greater freedom to choose their marriage partners. The controls on women's migration should also be understood against the backdrop of the need to preserve circulatory male labour-that the women were to remain in the rural areas to take care of the reproductive needs of men (Marks \& Unterhalter 1978: 12). However, with the passage of time this situation was disrupted by the very migrant labour, as marital prospects and marital unions were curtailed by the long absences. These controls served to entrench and maintain women in a system of perpetual socio-legal subservience.

Amongst Bakgatla, in 1930 the Chief gave South Africa Railways permission to extend the road motor service from the Transvaal into the Reserve, only on condition that "his own men would be employed as bus conductors, to see that women did not use the service as a means to escape from home" (Schapera 1947: 90-91). Although the phenomenon had started to register in the 1930's, by the 1940's, women's migration had taken on such serious proportions and that it caused serious concern among "tribal" elders, although it still lagged far behind that of men (Schapera 1947). Various pressures were brought to bear on women, ranging from official sanction to tribal prohibition, which was done within the purview of the customary law.

62 Amongst Bangwato, a customary law was formulated, specifically to prevent women from leaving the (Bangwato) reserve by rail except on the Chief's permission (Schapera 1947: 90). To this end, representatives were placed at places such as Shashe, Palapye, Mahalapye and Palla Road to ensure that the law was not evaded (Schapera 1947: 90). This was the flipside of a practice known as "go kopa tsela" (literally meaning to ask for passage), where people were required to produce evidence of passage granted by the headman (ibid.). In the Tati District, a similar situation obtained whereby the sub-dikgosi 
declared that "no woman going to Rhodesia without permission would be allowed to return home". The object of this warning was to discourage and deter others from following their example (ibid.).

In some ways, traditional authorities and the colonial government were in concert over curtailment of women's movements across the border. The discomfort experienced by tribal and colonial authorities increased in direct proportion to the numbers of women moving to urban areas in particular. The colonial government favoured the sanctioning of single women from moving to urban areas, due to fears of liquor selling, prostitution, and a potential spread of disease, all of which would be disruptive to capitalist labour needs.

The concern about women's recruitment became so great that as early as 1924, the Native Advisory Council suggested that:

"Station masters should not issue train tickets to young women unless they are accompanied by their fathers and relatives, or bring a permit from the chief" (ibid.: 97).

To this call by the Native Advisory Council the Resident Commissioner apparently replied that:

“District Officers' had been instructed not to issue passes to young people without a permit from their Chief" (ibid.: 92).

The restrictions so imposed on youth affected women more than men because there were a number of recruiters including the Native Recruiting Company and the Witwatersrand Mining Labour Association (WENELA) (ibid.), whilst there were no comparable ones for women. The tribal or customary restrictions meant that a greater proportion of women constituted "independent" migrants, because that way they were able to avoid detection.

Through the 1930's and 1940's customary restrictions increased, as various controls were imposed, in some instances with the collusion of the Protectorate administration. Generally though it would appear that "any refusal (by the administration) to give people passes was done at the instance of either tribal authorities or foreign governments" (ibid.: 85). In 1952 the Native Urban Areas Consolidation Act was passed which required all African workers to carry passes which gave them authority to reside in town (Marks \& Unterhalter 1978: 12, quoted in Izzard 1979: 295). Compound regulations were also used to prevent Southern African women from following their migrant husbands to mining areas ${ }^{62}$. Similarly, influx control laws were imposed to control settlement in urban areas at other times. Passes were not required for women and children until the late 1920's. As previously observed, this conformed to the needs of capital, since women continued to provide the complimentary needs of capital back in the rural areas. Women had a special role as mothers and carrying on the agricultural activities that were traditionally a woman's domain, until the plough came into the picture, and inadvertently pushed women to the periphery of agricultural production.

68 It would appear however that there were times when the needs of capital overrode those of tribal authorities, and instead benabled women to be gainfully employed. For example, in both the Transvaal and the Orange Free State, the main sources of employment for Batswana, if the latter were found without passes, the police merely ascertained whether they had clear records, and if so, they were given temporary permits, which they used to search for work ${ }^{63}$. The decision to "turn a blind eye" to 
illegal migrants was also linked to scarcity of domestic and farm labour in South Africa $^{64}$.

Moreover, In spite of the various restrictions placed on their recruitment, it would seem that by the late 1940's the pass laws merely served as obstacles to migration, rather than a deterrent (ibid.: 90). It would generally that women managed to find ways of getting around these "tribal" sanctions and patriarchal strangleholds, as "a fairly considerable number of them still managed to get away" (Schapera 1947: 64). Interestingly, women continued to cross the border even after the introduction of passport requirements on external migrants (Mme Dopiwa, interviewed in Mathathane, April 2007). Unfortunately, there are no statistics available which indicate the number of Batswana who were found without passes, and were either arrested, or returned home. Based on information gleaned from oral sources, it would appear that, due to Batswana-South African socio-cultural ties, Batswana who crossed unofficially (or illegally) into South Africa were generally not bothered, and easily mingled either with kith or kin, who also helped them to secure jobs (Focus group interviewed by author in Mathathane, April $7^{\text {th }}$ 2007). In addition, the fact that up until the independence of Botswana in the mid-1960's there had been little border patrol, many of the people in the border areas were able to easily cross back and forth at different periods either in search of work, or to visit relatives (Focus group interview, Mathathane, April $7^{\text {th }}$ 2007).

It also seems that with the passage of time, as "tribal" control became more diluted by other changes happening in the political economy ${ }^{65}$ as well as the previously observed changes in Botswana's value-system and world view, the mobility of younger and unmarried women gradually became more acceptable. This acceptance was enabled and mediated by other forces, such as schooling and paid employment, which opened up more avenues for women to leave home, in order to help to sustain their families.

Women's Migration and Productive Relations

71 It was observed previously that agricultural productivity was gradually undermined by the absence of able-bodied men. The general deterioration in cattle herding was repeatedly expressed by the "Native" Advisory Council in its meetings (Schapera 1947; Wikan 1981; van der Wees 1981). The extent to which migration negatively affected pastoral farming was governed by the nature and extent of kin networks and support systems. For example, where the traditional systems of mutual help were still intact, the effects of labour migration tended to be minimised, and vice versa. In general however, most households were adversely affected, particularly due to the fact that the system of "mafias" and other patron-client network systems were weakened by increasing individualism.

72 Cross-border migratory labour also gave rise to the incidence of female- headed households which have for various reasons, did not fair well in subsistence, let alone in commercial agriculture. Consequently, the household as a social unit became more and more matrilineal and less less patrilineal-men going out to work and women remaining as heads of households. Migration also brought about irrevocable changes in relation to farming practices, which had far-reaching effects on other spheres of men's and women's lives. As Schapera (1936) noted:

"In the olden days it was tabu (sic) for women to have anything to do with the cattle. They neither herded cattle nor milked them. When the plough was introduced, and it became necessary to harness the oxen the men for the first time began to take a more active part in agricultural routine, not only because of the 
greater labour involved, but also because women were still debarred from handling cattle." that women (who remained behind) began to occupy and serve in capacities in which they were previously not permitted under customary law. In particular, women increasingly played a greater role in agriculture, community activities, and decision making within the household. This laid the foundation for women's greater involvement even in socio-political spheres outside the home, such as work in development projects, as in the work of Village Development Committees ${ }^{67}$. The changes that occurred in the wider political economy also aided the negation of some aspects of customary law, such as curtailment of the powers of dikgosi, as previously noted.

Political Changes and Women's Socio-legal Status

77 Entrenchment of the colonial enterprise was reflected in changes that occurred in the political sphere as well. Whilst some dikgosi were able to exploit their relationship with missionaries and the colonial government to enhance their power, such power did not remain unfettered. Colonization of Batswana territory meant that the authority of dikgosi was at once strengthened and undermined (Maylam 1980: 217). Under the Order 
in Council of 1891, dikgosi had been allowed to continue ruling over their own people, except in criminal cases, or cases involving a non-Africans. On one level dikgosi were colonial collaborators as they received $10 \%$ commission on all tax collected (Colclough \& McCarthy 1980: 19). On another level they were also victims of colonization, as their authority was gradually prescribed.

The most potent signal of colonial interference in dikgosi's political control occurred through the passing of Proclamations no. 74 and no. 75 of 1934, which were imposed under the rubric of administrative reforms. These proclamations reduced dikgosi's powers and brought the traditional leadership more closely under the control of the colonial government ${ }^{68}$. Although the reforms derived from broader international reasons centred upon the reassessment of Britain's role in the colonies at the time (Sillery 1974: 132, quoted in Colclough \& McCarthy 1980: 24), they were also embarked upon specifically to arrest the hitherto unfettered chiefly authority and power. It was determined that the dikgosi activities had in some cases resulted in abuses of power and exploitation of their own people, sometimes through extreme financial extortions (Colclough \& McCarthy 1980: 24). The reductions of dikgosi' powers and the colonial interference in the political economy opened up one avenue of challenge to some of the traditional practices, rules and governance laws, of which the dikgosi were custodians.

Hence, it can be argued that it was largely due to the interference of missionaries and the colonial government in many sphere of the lives of Batswana therefore, that dikgosi gradually made changes to customary laws (Schapera 1955) ${ }^{69}$. The extent to which directly affected women's legal status could be gauged from the fact that (Christian) women who were influenced by the Church to challenge their husbands' polygamous transgressions ${ }^{70}$. The Protectorate (Common) Law also allowed for divorce suits against marriages solemnised by missionaries to be heard before a magistrate (Schapera 1988: 158).

Increasingly also, the interaction of customary and common laws gradually let up on exclusive male control of other critical resources including wage employment and land rights. Labour mobility ${ }^{71}$ and migration contributed immensely to these processes. It was also largely due to migration (despite controls on women's mobility), that women were able to gain independent access to cash-a new and crucial exchange commodity. In this way, some women were able to attain an enhanced socio-economic status. As the colonial milieu unfolded in this way, so women's status was also transformed.

Postcolonial Urbanization and Intra-national Migration

81 It is interesting to note that some of the trends that occurred during the colonial times were replicated in intra-national migrant trends in post- independent Botswana, although they were mediated by other factors. In the early part of the postcolonial period, migration to towns increasingly in proportion to the demands for education, combined with the concentration of schooling opportunities in towns and major villages attracted larger numbers of both males and females to these areas (Wells 1978). The preponderance of employment opportunities in the agro- towns and industrial towns also drew people further and further away from farming and more and more towards paid employment (van der Wees 1981). This served to entrench and intensify a development that occurred during cross border migration observed previously.

Due to the restrictions that were generally imposed on outsiders to work in the South African mines in the 1970's, (Brown 1983), the proportion of intra-national migration gradually rose (Colclough \& McCarthy 1980). This development was largely fuelled by 
Botswana's mineral discoveries and mineral discoveries and commencement of mining diamonds at Orapa, copper and nickel at Selebi-Phikwe.

Whilst men had more varied avenues for employment in towns, women initially participated in gender stereotypical vocations in the informal sector, in line with the type, nature and levels of education they had acquired. These mainly served the reproductive needs of (male-anchored) labour capital in the nascent urban economy. They were vocations were in the traditionally female stereotyped sectors of domestic work, petty commodity trading. For those who had received higher levels of education employment avenues opened up in teaching and care giving, or nursing, etc. Due to increasing awareness of the economic benefits of schooling and better provision of education in urban centres, from the late 1970's however, women increasingly migrated to towns and major villages for this purpose as well. Education itself became the enabling process for women's independent (and deliberate) move to towns, as more and more women entered the labour force.

Within this development a new trend began-that of women whose migration was facilitated by education, and were venturing into towns to take up formal employment. But part of the fuel for migration, was also due to the need to access higher and better education which were established mainly in the urban centres and big villages. In view of the fact education development had been so severely curtailed during the colonial period, it received the highest allocation of the development fund. Moreover, educational expenditure comprised the biggest proportion of the budget which resulted in rapid and unprecedented levels of educational expansion (Colclough \& McCarthy 1980: 212).

This development was made imperative by the fact that the newly independent state required personnel to drive its burgeoning political economy.

Increasingly, Migration for Purposes of Accessing Educational Facilities became Significant

The combination of reduced agricultural production and lack of rural development also led to a rapid growth in internal migration. Hence, from the 1980's the government of Botswana began a series of programs aimed at arresting the rising tide of rural-urban migration. These included assistance to brigades that were operating in the rural areas, to encourage rural employment and promotion of rural industries, with little success. Gender dynamics governed and under-girded these processes. It was manifested by differential access to brigades training, and differential outcomes and benefits of such training (Fidzani \& Mafela 1994).

Due to changes that occurred in the productive base, the reproductive sphere also registered changes which closely mirrored those that had occurred earlier. Hence, in the postcolonial period too, a high number of unmarried young women and girls have increasingly been able to migrate to towns. The cycle of their activities reflects a pattern whereby they generally return home to have children, only to go back to towns, leaving their children in the care of their mothers and grandmothers. This has exacerbated the incidence of matri-lineality and matrifocality, which is in some cases not only a result, but also a reflection of the growing numbers of female-headed households (NMS 1979). Matrilineality and matrifocality primarily resulted from men's (protracted) absence and abandonment of women (Izzard 1979). But secondarily, these two developments were a consequence of older women (mothers and granddaughters) being primarily responsible for raising children, whilst the biological mother (the 
younger woman of the family) would be earning a livelihood to support the rural homestead (ibid.; Brown 1983). These processes did not only increase the burden on (the older) women, but also irrevocably affected Batswana social relations of production. For example, Brown (1983) observed that amongst Bakgatla in the 1970's, women were "mother", "wife", "caregiver" all rolled into one. The notion of women who were also "fathers" due to the absence of the biological fathers could be added to the list. Batswana can no longer always be relied on to serve the role which their previously served, as a support system for their sisters and mothers, paying their sister's schools fees or the bogadi (bride price) for their sisters' sons. By the same token, it would be expected that women's lessened reliance on men for sustenance has also lessened male effective control over women.

Thus, in the post independence period, migration to the urban centres continued to exert pressures on productive and social relations that had been previously shaken by cross-border migration. Moving to, and staying within the urban environment has had mixed effects on the women's socio-economic status, and through that on their legal status, as well.

In terms of women's socio-legal status, post-colonial democratic governance added impetus to transformations to the political economy, where there has been convergence of the traditional and western style democratic principles. This development has in some cases aided the women's course. For example, women have gradually (encroached) into the political sphere, where they have been able to access citadel of male symbolic and socio-political authority and control-the kgotla. Women have not only been able to break through century-old barriers, but have also been able to participate in, and influence decisions on matters that are discussed at the kgotla and other structures, albeit to a lesser extent than $\operatorname{men}^{72}$. They ahve also increasingly accessed parliamentary and cabinet positions ${ }^{73}$.

The national and international women's rights activism have shaken, although not overturned the status quo in regard to women's marginalization. This is partly due to the fact that by and large the common law rules of procedure are in line with constitutional provisions the exclusion of customary law from this legal milieu has created bottlenecks for women's attainment of equality. Due to its negotiability, it has ensured that gender relations have become renegotiated and reorganised into new forms of women's marginalization (Radijeng 2004).

91 Generally, the extent to which women are able to get legal recourse depends on their ability to negotiate their position (Griffiths 1996). Research highlights the complex layers of systemic patriarchal control to which women are subjected in trying to get recourse for issues around many issues affecting their lives. This included the fact that under customary law, cases continued to be presided over by men and from a maleoriented viewpoint about customary matters (ibid.: 206).

Since the pre-colonial period, Batswana women have endured patriarchal domination and control over their lives. In pre-colonial society, women's personal lives and sociolegal status were curtailed by strictly prescribed patriarchal-social codes of behaviour based on traditional norms, rules and practices. The advent of missionary and colonial rule brought about some transformation to women's lives and individual positions and status, which were in some cases affirming, and in other cases recasting existing notions of women's position in society. In some ways, the individualism that resulted from missionary and colonial processes mediated women's status, while in other ways 
it restricted them to the domestic domain. Nonetheless, the further spread of western educational and commercial processes amongst Batswana also opened up avenues for individual women to venture out of the household and into waged employment-which proved a challenge to Batswana men's exclusive control. In particular, it was the process of labour migration which simultaneously liberated and restrained women. It placed the women at the centre of household decision- making, in the absence of men, and which enabled them to access education in larger numbers than men. However, in the sending areas, women's productive burden was intensified, and as they had to play multiple roles, economically and socially, in the absence of the men. Thus, migration has been both a curse and a blessing for women's socio-legal position.

Economic migration accorded migrating men and women the means to an improved livelihood, as well as the opportunity to unshackle themselves from the bondage of traditional obligations. Nonetheless, migration also resulted in the transformation of the household unit from being almost exclusively patrifocal to being largely matrifocal. In some ways this has had deleterious effects on the (current) form and functioning of the Tswana household unit. In some cases these processes have benefited women, whilst in other cases they have made women more vulnerable socioeconomically.

Education itself reflected, and was in turn reflected (in) the processes which were set in motion by colonial discourse. Moreover, Batswana also accessed education, increasingly through mobility and migration outside their immediate environment. Women's mobility in these processes directly contravened the customary laws and controls, and resulted in attempts to sanction their independence.

The quest for better educational opportunities has also contributed significantly to post-independence rural-urban migration. However, women's education continues to be mediated by early pregnancies, resulting in high levels of school drop-outs. This affects girls' higher education, wage employment and life chances generally. Lowered life chances tend to affect women's ability to access resources, including crucial networks, and power to negotiate in everyday life and within a socio-legal context (Griffiths 1998: 130) ${ }^{74}$.

\section{BIBLIOGRAPHY}

BONNER, P.

1990 "Desirable or Undesirable Basotho Women, Liquor Prostitution and the Migration of Basotho Women to the Rand, 1920-1945", in C. WALKER (ed.), Women and Gender in Southern Africa to 1945 (Cape Town: David Philip): 221-250.

BOSERUP, E.

1970 Women's Role in Economic Development (London: George Allen \& Unwin). 
BOTSWANA GOVERNMENT

1982 Final Report of the National Migration Survey (Ministry of Finance and Development Planning, Gaborone: Government Printer).

BozzoLI, B.

1991 Women of Phokeng, Consciousness, Life Strategy and Migrancy in South Africa, 1900-1983

(Portsmouth: Heinemann; London: James Currey).

BROWN, B.

1983 “The Impact of Male Labour Migration on Women in Botswana”, African Affairs 82 (328):

367-388.

BUDE, $\mathrm{U}$.

1983 “The Adaptation Concept in British Colonial Education", Comparative Education 19 (3):

341-355.

BUNDY, C.

1977 “The Transkei Peasantry, c. 1890-1914”, in R. PALMER \& N.PARSONS (eds.), The Roots of Rural

Poverty in Central and Southern Africa (London-Ibadan-Nairobi: Heinemann): 201-220.

Chirenje, M.

1977 A History of Northern Botswana, 1870-1910 (London: Oxford University Press).

Colclough, C. \& McCarthy, S.

1980 The Political Economy of Botswana: A Study of Growth and Distribution (Oxford: Oxford University Press).

COMAROFF, J.

1985 Body of Power and Spirit of Resistance: The Culture and History of a South African People (Chicago: University of Chicago Press).

COMAROFF, J. \& COMAROFF, J.

1991 of Revelation and Revolution: Christianity, Colonialism and Consciousness in South Africa, Vol. 1

(Chicago: University of Chicago Press).

1992 "Home-made Hegemony: Modernity, Domesticity and Colonialism in South Africa", in K. T.

HANSEN (ed.), African Encounters with Domesticity (New Jersey: Rutgers University Press): 37-74.

ETTINGER, S. J.

1972 "South Africa's Weight Restrictions on Cattle Exports from Bechuanaland, 1924-1941", Botswana Notes and Records 4: 21-30.

FAwcus, P. Sir \& TILbuRy, A.

2000 Botswana: The Road to Independence (Gaborone: Pula Press and the Botswana Society).

FidzANI, N. H. \& MAFELA, L.

1994 A Report of the Evaluation Study of the Botswana Brigades (commissioned through the Botswana Educational Research Association and submitted to the Department of Vocational Education and Training (Gaborone: Ministry of Education).

GAITSKELL, D.

1992 “Sewing, Sexuality and 'Social Place': Mission and State, Perspectives on African Girls' Education in South Africa before 1953", paper presented to a Conference on Missions and the State in the Third World, Held in Rostlke, Denmark, May 27-20 (Copenhagen and the Institute of Commonwealth Studies Program: University of London). 
GENOVA, J.

2004 "Conflicted Missionaries: Power and Identity in French West Africa during the 1930's", The Historian 66 (1): 45-66.

GRIFFITHS, A. M. O.

1986 “What is Legal Pluralism?", Journal of Legal Pluralism 24: 1.

1996 "Between Paradigms: Differing Perspectives on Justice in Molepolole, Botswana", Journal of Legal Pluralism 36: 206.

1997 In the Shadow of Marriage: Gender and Justice in an African Community (London: University of Chicago Press).

1998 “Legal Pluralism in Botswana: Women's Access to Law”, Journal of Legal Pluralism (42):

124-135.

2004 "Customary Law in a Transitional World, Legal Pluralism Revisited", Paper prepared for a Conference on Customary Law in Polynesia, $12^{\text {th }}$ October. <http://www.lianz.waikato.ac.nz/

PAPERS/symposium/Customary\%20Law\%20in\%20a\%20Transnational\%20World.pdf>.

GUGLER, J.

1972 The Second Sex in Town, La Revue Canadienne des Études africaines, VI (II): 289-301.

GuY, J.

1990 "Gender Oppression in Southern Africa's Pre-capitalist Societies", in C. WALKER (ed.), Women and Gender in Southern Africa to 1945 (Claremont: David Phillip Publishers): 33-47.

HAILEY, Lord

1953 Native Administration in British High Commission Territories, Part V: The High Commission Territories (London: Her Majesty's Stationery office).

HALPERN, J.

1965 South Africa's Hostages. The High Commission Territories: Botswana, Lesotho and Swaziland (Baltimore: Penguin).

HANSEN, K. H. (ed.)

1992 African Encounters with Domesticity (New Brunswick: Rutgers University Press).

HONDAGNEU-SOTELO, P.

1994 Gendered Transitions: Mexican Experiences of Immigration (Berkeley-Los Angeles: University of California Press).

HUNT, N. R.

1992 "Colonial Fairy Tales and Knife and Fork Doctrine in the Heart of Africa", in K. T. HANSEN

(ed.), African Encounters with Domesticity (New Brunswick: Rutgers University Press): 143-171.

IZZARD, W.

1979 National Migration Study: Rural Urban Migration of Women in Botswana, Final Fieldwork Report, August (Gaborone: Government Printer).

JEATER, D.

1993a "Review: Elizabeth Schmidt, Shona Women: Peasants, Traders and Wives: Shona Women in the History of Zimbabwe, 1870-1939", Journal of African History 34 (3): 526-528.

1993b Marriage, Perversion and Power: The Construction of Moral Discourse in Southern Rhodesia 1894-1930 (Oxford: Clarendon Press).

Kalabamu, F. T.

2004 Perceptions on Negotiated Customary Inheritance in Botswana (Gaborone: University of Botswana). 
2005 "Changing Gender Contracts in Self-help Housing Construction in Botswana: The Case of Lobatse", Habitat International 29: 245-268.

2006 Patriarchy and Women's Land Rights in Botswana, Land Use Policy (23): 237-246.

KERVEN, C.

1984 Academics, Practitioners and All Kinds of Women in Development: A Reply to Peters, Journal of Southern African Studies 10 (2): 259-268.

KING, K.

1971 Pan-Africanism and Education: A Study of Race Philanthropy and Education in the Southern States of America and East Africa (Oxford: Clarendon Press).

KINSMAN, M.

1983 "Beasts of Burden: The Subordination of Southern Tswana Women, 1800-1840", Journal of Southern African Studies 10 (1): 39-54.

KOWET, D. K.

1978 Land, Labour Migration and Politics in Southern Africa, Botswana, Lesotho and Swaziland (Uppsala: Scandinavian Institute of African Studies).

KUSTER, S.

1992 Neither Cultural Imperialism Nor Precious Gift of Civilization, African Education in Colonial Zimbabwe, 1890-1962 (Hamburg: Die Deutsche Bibliothek, CIP Einheitsaufnahme).

Kyomuhendo, G. \& Keniston, M.

2007 Women, Work and Domestic Virtue in Uganda, 1900-2003 (Oxford, Ohio: James Currey).

LERNER, G.

1986 The Creation of Patriarchy (Oxford: Oxford University Press).

LUGARD, F.

1922 The Dual Mandate in British Tropical Africa (Edinburgh: William Blackwood \& Sons Ltd).

MAFELA, L.

1993 Competing Gender Ideologies in Education Amongst Batswana, c. 1840-c. 1966, Ph. D. Dissertation (Evanston: Northwestern University).

1994 "Mochudi Homecraft Centre: Training Batswana Women for a Euro- Western Type of Womanhood", Mosenodi: Journal of the Botswana Educational Research Association 2 (1): 3-16.

MARKS, S. \& UNTERHALTER, E.

1978 "Women and Migrant Labour System in Southern Africa", in the Report of the ECA, Conference Migratory Labour in Africa, Lusaka.

MARKS, S. \& RATHBONE, M. (eds.)

1982 Industrialisation and Social Change in South Africa: African Class Formation, Culture and Consciousness, 1870-1930 (London: Harlow).

MASSEY, D.

1981 Labour Migration and Rural Development in Botswana, Ph. D. Dissertation (Boston: Boston University Press).

MAYLAM, P.

1980 Rhodes, the Tswana and the British: Colonialism, Collaboration and Conflict in the Bechuanaland Protectorate, 1885-1899 (Westport: Greenwood Press).

MOFFAT, R.

1842 Missionary Labours and Scenes in Southern Africa (London: Snow). 
MoLокомme, A.

1984 "The Legal and Cultural Barriers which Prevent Women from Full Participation in National Development: Some Proposals for Change", in Report on the National Conference on Women in Botswana: Strategies for Change, Held in 1983, Gaborone: Ministry of Home Affairs: 11-21.

1990 “Women's Law in Botswana: Laws and Research Needed”, in J. E. STEWART \& A. ARMSTRONG (eds.), The Legal Situation of Women in Southern Africa, Women and Law in Southern Africa (Harare: University of Zimbabwe Publications).

Molokomme, A. \& Selolwane, O. et al.

1998 Review of all Laws Affecting Women in Botswana, Final draft prepared for the Women's Affairs Department (Gaborone: Ministry of Labour and Home Affairs).

MORROW, S.

1986 “"No Girl Leaves School Unmarried': Mabel Shaw and the Education of Girls at Mbereshi, Northern Rhodesia, 1915-1940", International Journal of Historical Studies 19 (4): 601-635.

MungAZI, D. A.

1982 The Underdevelopment of African Education: A Black Zimbabwean Perspective (Washington DC: University Press of America).

1991 Colonial Education for Africans: George Stark's Policy in Zimbabwe (New York: Praeger).

Musisi, N. B.

1992 “Colonial and Missionary Education: Women and Domesticity in Uganda, 1900-1945”, in K. T. HANSEN (ed.), African Encounters with Domesticity (New Brunswick: Rutgers University Press):

172-194.

PALMER, R. \& PARSONS, Q. N. (eds.)

1977 The Roots of Rural Poverty in Central and Southern Africa (London: Heinemann).

PARSONS, N. Q.

1977 “The Economic History of Khama's Country in Botswana, 1844-1930”, in R. PALMER \&

N. PARSons (eds.), The Roots of Rural Poverty in Central and Southern Africa (London: Heinemann):

113-142.

PESSAR, P. R. \& MAHLER, S. J.

2001 "Gender and Transnational Migration", Paper given to the conference of 30 June-1 July, Transnational Migration: Comparative Perspectives (Princeton: Princeton University Press).

2003 “Transnational Migration: Bringing Gender in”, International Migration Review 37 (3): 812-846.

PIM, A. Sir

1933 Report of the Financial and Economic Position of the Commission Appointed by the Secretary of State for Dominion Affairs (London: His Majesty's Stationery Office, [The Pim Report]).

RADIJENG, G. O.

2004 Customary Law and Gender Equality: The Legal Status of Women in Botswana, D. Phil Thesis (Hilary, Exeter College).

RICHARDSON, J.

1899 Report on the Inspection of Bechuanaland Schools, July-September 1899, LMS Outgoing Letters, 1868-1914, Boxes 12-41 (Council for World Mission Archives).

SARGANT, E. B.

1908 Report on Education in South Africa, Part III, Education in the Protectorates 52 (Surrey: Headly).

SCHAPERA, I.

1936 "The Contributions of Western Civilization to Modern Kxatla Culture", Transactions of the 
Royal Society of South Africa 24: 221-252.

1938 Mekgwa le Melao ya Batswana (Alice: Lovedale Press).

1943 Native Land Tenure in the Bechuanaland Protectorate (Alice: Lovedale Press).

1947 Migrant Labour and Tribal Life; A Study of Conditions in the Bechuanaland Protectorate (London: Oxford University Press).

1955 A Handbook of Tswana Law and Custom (London: Frank Cass \& Company).

1970 "The Political Organisation of the Ngwato of Bechuanaland Protectorate", in M. FORTES \&

E. E. EVANS-PRITCHARD (eds.), African Political Systems (London: Oxford University Press): 56-82. 1988 "Early European Influence on Tswana Law”, Journal of African Law 31 (1/2): 151-160.

SCHAPERA, I. \& ROBERTS, S.

1975 "Rampedi Revisited: Another Look at a Kgatla Ward", Africa 45 (3): 266-279.

SCHMIDT, E.

1992 Peasants, Traders and Wives: Shona Women in the History of Zimbabwe, 1870-1939 (Portsmouth: Heinemann; Harare: Baobab; London: James Currey).

ScoTT, J. W.

1988 Gender and the Politics of History (New York: Columbia University Press).

SHAW, M.

1986 "No Girl Leaves School Unmarried: Mabel Shaw and the Education of Girls at Mbereshi, Northern Rhodesia", International Journal of African Historical Studies 19 (4): 601-635.

SILLERY, A.

1974 Botswana: A Short Political History (London: Methuen).

SILVEY, R.

2006 “Geographies of Gender and Migration: Spatialising Social Difference”, IMR 40 (1): 64-81.

STEWART, J. E. \& ARMSTRONG, A. (eds.)

1990 The Legal Situation of Women in Southern Africa, Women and Law in Southern Africa (Harare: University of Zimbabwe Publications).

SUDARKASA, N.

1977 Women and National Development: The Complexities of Change, Signs 3 (1): 178-189.

TORRANCE, D. E.

1998 "Britain, South Africa, and the High Commission Territories: An Old Controversy Revisited", The History Journal 41 (3): 751-772.

VAN HOOK, M.

1994 "The Impact of Economic and Social Changes on the Roles of Women in Botswana and Zimbabwe", Affilia 9: 288.

VANQA, T. P.

1998 The Development of Education in Botswana: The Role of Teacher Organizations, 1937-1987

(Gaborone: Lightbooks).

WANDIRA, A.

1972 Early Missionary Education in Uganda: A Study of Purpose in Missionary Education (Department of Education, Kampala: Makerere University Press).

WEBER, $\mathrm{M}$.

1956 The Protestant Ethic and the Spirit of Capitalism (New York: Scribner Press). 
WEBSTER, N. \& MERRIAM, G. C.

1977 Websters' New Collegiate Dictionary (Toronto: Thomas Allen \& Sons Ltd).

VAN DER WEES, C. L.

1981 The Impact of Migration on Arable Agriculture; A Study in Eastern Botswana, BNA, BNB Micro 801.

1981 Migration and its Impact on Rural Botswana (Amsterdam: Free University Press).

WELLS, K. S.

1978 Migration to Gaborone: The Case of Primary School Leavers (Oxford: Regents Park College).

WIKAN, G.

1981 Absenteeism, Crop Cultivation and Level of Living in Rural Botswana, Translated and Abridged Version of Author's Thesis (Oslo: University of Oslo).

WiLlis, K. \& YеOH, B. (eds.)

2000 Gender and Migration (Cheltenham \& Northampton: Edward Elgar).

WILSA

1999 Chasing the Mirage: Women and the Administration of Justice (Gaborone: Women \& Law in Southern Africa).

ORAL INFORMANTS

Bome, interviewed in 1991, Kanye, Botswana.

Motshabi, interviewed in 1990, Serowe, Botswana.

Mme MmaKungo, interviewed in, 1990, Serowe, Botswana.

Focus group discussion with Mathathane Women: Dopiwa (nee Monegwe) aged 72, aged Sophie Nteda, aged 74, MmaMoloko Moribame aged 73; Kwere Monegwe, aged 69, interviewed in Mathathane, $7^{\text {th }}$ April 2007.

ARCHIVAL SOURCES

BNA, BNB 3957

BNA, BNB Micro 801

BNA ZKM/11

\section{NOTES}

1. The youth's coming of age was formally marked by formal ceremonies, which were championed by the Chief's eldest son. (SCHAPERA 1938).

2. Kgosi is a Setswana word akin to Chief. It is a more acceptable historiographical term than Chief. The plural form is dikgosi. The di- denotes the plural form.

3. Indirect rule policy depended on the use of indigenous political structures, and required minimal interference in the affairs of the colonised people. Consequently, it also required minimal costs in the administration of the territory (LUGARD 1922). Britain had annexed Bechuanaland primarily in order to create a buffer against German, Portuguese and Boer threats, so as to safeguard its own imperial interests (CHIRENJE 1977).

4. As Batswana themselves put it, "molao sekhutlo, moelwa oya", meaning the law has an end, it can be left behind, a Tswana proverb which was also uttered in initiation rituals (COMAROFF \& COMAROFF 1991: 128). It also meant "the law is evanescent or temporary" (Brown 1926, quoted in COMAROFF \& COMAROFF 1991: 128).

5. Rulership, or specifically, traditional Tswana rulership. 
6. The passing of Proclamations No. 34 and No. 35 were the most potent expression of these changes.

7. See a number of essays on African colonial education in K. T. HANSEN (1992); For comparisons with Zimbabwe see also E. SCHMIDT (1992) and Diana JEATER (1993a). For Uganda, see the more recent book (reviewed in this volume) by Grace KYOMUHENDO and Marjorie KENISTON (2007).

8. The Websters New Collegiate Dictionary (1977) defines patriarchy as "a social system of organization marked by the supremacy of the father in the clan or family, the legal dependence of wives and children, and the reckoning of descent in the male line". 9. The village meeting place and seat of political power, from which women were barred. Exceptions are women who acted as regents during the minority of their sons, such as Ntebogang of BaNgwaketse and Pulane Moremi of Batawana.

10. According to facts and figures based on the last (2001) population census, $47 \%$ of house-holds are female-headed. The proportion of male to female Batswana is $69.9 \%$ to 73\% (Women and Men in Botswana, Facts and figures, Central Statistics Office, Government Printer, Gaborone, 2006, p. 4).

11. For a more detailed discussion of Tswana traditional socio-economic and political structures, Schapera's works are highly informative. In particular, see SCHAPERA (1938, 1955), COMAROFF \& COMAROFF (1991).

12. In the capitalist-oriented and individualist economy of present-day Botswana, this historical antecedent has not augured well for the socio-economic status of women. However, western education has historically partly mediated this problem by affording some women access to an independent source of income and potential individual socioeconomic status.

13. The word bogosi is more acceptable than Chieftaincy in Botswana historiography.

14. Amongst some Batswana groups such as Baherero, women herded cattle.

15. A method by which young calves were branded (as a way of distinguishing them from the rest of the herd), and presented as gifts (usually to his sons).

16. Literally, meaning "escort".

17. Meaning small basket. It denotes the diminutive form of "seroto" which means, "basket".

18. This paper will be concerned with the territory which constitutes present-day Botswana. It was renamed Bechuanaland Protectorate when it was annexed by Britain in 1885. It was subsequently renamed Botswana in 1966 upon attainment of independence in 1966.

19. These ranged between 600 pounds to 1,000 pounds by 1909 (CHIRENJE 1977: 184).

20. African rejection of some aspects of missionary and colonial education, particularly its "manual" orientation was widespread in colonial Africa (WANDIRA 1972; MUNGAZI 1982; BUDE 1983; KUSTER 1992; MAFELA 1993).

21. Demonstrations on irrigation and the use of the plough were carried out here. The mission station also housed the first printing press where the bible was translated into the Setswana language.

22. The LMS Tiger Kloof Institution was in fact built outside the territory of Batswana. It was located between Vryburg and Kimberly in South Africa. However, it served Batswana educational needs from its opening in 1904 as a boys-only institution until 1955 when it was shut down, following the implementation of the discriminatory Bantu Education Act by the apartheid South African government. The LMS relocated the 
institution to Otse in present-day Botswana in and renamed it Moeding College, where it is currently operates as a government- aided mission Secondary School.

23. Similar objectives were also pursued in other mission institutions at the time (for e.g. the Mbereshi and Gayaza Girls' Boarding Schools and Inanda Seminary noted above).

24. Some of these rules were directed at African sexuality itself. Diana JEATER (1993b) explores how Black Zimbabweans sexuality was regulated through a series of morallydirected rules of behaviour. In the final analysis these rules of behaviour came to affect the social identity of Africans and transformed it more and more away from its lineage basis and more and more towards its individual basis.

25. Sekgoa as contrasted to Setswana, means the European way and Setswana means the Tswana way (of doing things) respectively COMAROFF \& COMAROFF (1991: 194).

26. See Max WeBER (1956).

27. Marginalization of (women's greater role in) household agricultural economy as a result of men's role in commercialized agricultural production has been reported in other parts of the continent, See for example, SCHMIDT (1992), BOSERUP (1970).

28. Batswana started migrating to the mines in 1870 when the Kimberly diamond commenced operations.

29. Bechuanaland was colonised primarily to protect British imperial interests (CHIRENJE 1977: 131-133; KOWET 1978: 35). In particular, Britain used the territory to create a strategic "buffer" zone between the Germans in German West Africa and the Transvaal Boers and other foreign powers, in order to protect the imperial "Road to the North" from Cape to Cairo. It was envisaged that the British would use this route to connect their imperialist interests across the continent, stretching from the Southern tip to the North.

30. The colonial policy of general neglect that was adopted towards the territory at the time of colonization was particularly manifested in the education arena. Hence, in spite of the fact that Batswana began receiving western education very early on, at independence, the state of literacy in the country was extremely underdeveloped due to virtual neglect on the part of the colonial government (COLCLOUGH \& MCCARTHY 1980: 205). See also, HALPERN (1965).

31. The cattle and dairy industries were the only areas of notable economic activity. However, even these were dominated by white cattle ranchers. Moreover, cattle diseases and the protracted weight restrictions imposed on cattle from Bechuanaland Protectorate made these ventures risky to pursue, particularly for cash strapped indigenous population (ETTINGER 1972).

32. Many Batswana societies originated in South Africa and later settled in present day Botswana. Many of the maintain cross-border socio-cultural ties. Among Bakgatla have a paramount Kgosi who resides in Botswana, but rules over the two groups of Bakgatla residing in Mochudi Botswana and at Moruleng in South Africa, near Rustenburg. 33. Khama's initial resistance to mine labour recruitment rescinded in 1913, due to economic hardships arising from crop failure, the rinderpest cattle disease and the collapse of the South African market (TORRANCE 1998).

34. Interview with Mme MmaKungo, Serowe, 1990.

35. Many Batswana attended schools at South African institutions, such as Lovedale, Adams College, Healdtown, and Ohlange Institute. Those in the North of the country also went to schools in the neighbouring Southern Rhodesia, which was another British colonial outpost also linked to the South Africa political economy. 
36. After the establishment of Tribal Treasuries in 1938, partial financing was secured to pay for teachers' salaries, books and maintenance of school buildings (COLCLOUGH \& MCCARTHY 1980: 206).

37. Some Batswana dikgosi imposed educational levies to raise funds with which they built community (merafe) schools. These efforts were initially geared to serve the primary school level, but were later extended to the secondary school level. This was started independently by dikgosi in 1903 and was extended by the government to the rest of the territory in 1919 (COLCLOUGH \& MCCARTHY 1980: 206).

38. Through the efforts of Batswana themselves, secondary education was only introduced in the 1940's. By independence time only a handful of these had been established.

39. There are many testimonies given by women, which indicate that the education (especially higher education) of their brothers was regarded more favourably, because as women they would sooner get married and hence presumably be lost to their family. Also see MAFela (1993).

40. There were similarities with French West African educational trends, since the schools were almost entirely masculine spaces, with very few girls attending. The kind of elite forged through the schools was highly gender-specific with strong misogynistic tendencies (GENOVA 2004).

41. For Belgian Congo, see Nancy Rose HUnT (1992); for Uganda, see Nakanyike B. MusisI (1992); for insights on Zimbabwe, see also Diana JeATER (1993b); for Zambia see Sean MORROW (1986).

42. For Botswana see MAFELA (1993); for East Africa see for example, Kenneth KING (1971) and U. BUDE (1983), and for Zimbabwe see MUNGAZI (1991).

43. See KUSTER (1992) and, 1982 for comparisons with Southern Rhodesia (Zimbabwe).

44. Based on the education models of the Tuskegee and Hampton institutes in the American South.

45. See Report of Education in Africa: The First Phelps Stokes Commission on Africa, July $15^{\text {th }}, 1920$-September 10, 1921; Report of Education in Africa: A Study of East, Central and Southern Africa, by the Second African Education Commission under the Auspices of the Phelps Stokes Fund, in Cooperation with the International Education Board, 1923-1924, Botswana National Archives (BNA): ZKM/11.

46. Following these Commissions, African education systems around the continent were re-orientated ostensibly to forge closer school and community integration, in line with the ideological needs of the colonial states. These institutions were uniform in their adherence to strict gender-specific curricula and in their "practical" orientation and adaptation of African education to the perceived role of Africans in the changing economic conditions of their colonies.

47. Similarly, Black Zimbabwean resistance to "manually-oriented" colonial curricula led to both covert and overt action, including strikes and passive protest expressed through extra-territorial educational migration particularly to South African institutions. See for example, KUSTER (1992), MUNGAZI (1982).

48. Its student body included sons of dikgosi and other influential members of the society.

49.The increasing competition among missionary bodies may have also indirectly helped to forge closer cooperation with indigenous communities, and to be more responsive to their needs. 
50. The Setswana word "Makgoanyana" is derived from the word "makgoa", meaning whites. The "nyana" is the diminutive form denoting affection, and by derivation, envy. 51. As educational options increased, in more recent times, as domestic education has increasingly been less favourably regarded, and has lost much of its past attraction. 52. The South African institutions at Lovedale and Fort Hare were favoured as educational destinations for Batswana during the colonial period.

53. Botswana is straddled by the Kalahari Desert, which made it extremely difficult to navigate, particularly in the early years when the road infrastructure was even poorer. Consequently, for a long time, educational developments were confined to schools that lay along the railway line, which was the main mode of transport. This state of affairs ultimately affected accessibility both for educational and employment purposes.

54. Chasing the Mirage: Women and the Administration of Justice, Gaborone: Women and Law in Southern Africa (WILSA), 1999, p. 17. The intersection of these dynamics continues to inform and define present-day social relations and interaction.

55. For other discussion about differential treatment of teachers on the basis of gender during the colonial and immediate post-colonial period.

56. The meaning of "higher" education evolved as education became more deeply entrenched in Tswana society. In the initial stages it meant beyond the lower levels of primary schooling, whatever they were considered to be at different times. In the later stages, "higher" came to denote more and more post-primary schooling in conformity with the way it was conceptualized over time.

57. Domboshava Agricultural Institution for example, also admitted students from Botswana. In the 1960's and early 1970's, Batswana also went to Lesotho for University level studies at the Roman Catholic Mission Pius College. This College was the precursor to the University of Botswana, Lesotho and Swaziland.

58. However, there were some men who were not "officially" enlisted, but who managed to get employment in other economic concerns, such as farming (Sophie Nteda, interviewed at Mathathane April 2007).

59. These appeals were made during Native Advisory council meetings increasingly from the 1940s (SCHAPERA 1947).

60. Present day Zimbabwe.

61. If the widow was young enough, the customary law allowed her to remarry (SCHAPERA 1947: 68).

62.The restrictions of the compound system dictated this type of situation, which was different from what transpired in West Africa amongst the Yoruba (SUDARKASA 1977: 178), where women were able to follow their husbands to their places of work. 63. This situation would serve to explain why men like RreMotshabi, was able to keep crossing into South Africa, seemingly at ungazetted points without a pass, in the late 20's and early 30's and yet always got employed, each time in the Transvaal (MAFELA 1993).

64. For a fuller discussion of this issue on how under similar circumstances, Basotho women survived detection and deportation in the Rand, see P. BONNER (1990).

65. For example, the gradual reduction of the powers of dikgosi's and the effects of modern legislative provisions, which were gradually extended to Batswana as well, particularly in the post-independence period.

66. These may have been the roots of the current problem of high levels of teenage pregnancy in Botswana. This causes enormous challenges, particularly in view of the high HIV/AIDS prevalence rate. 
67. Participation in these was however never devoid of male control, as men are often chairpersons of VDC's. Women were also able to get their foot in to western schools ahead of men, although the myriad of customary (productive and reproductive obligations quickened their exit, as previously shown).

68. Some dikgosi fought vehemently to oppose these laws, particularly Tshekedi (COLCLOUGH \& McCARTHY 1980: 25).

69. As Batswana themselves put it, "molao sekhutlo, moelwa oya", a Tswana (Rolong dialect) proverb, which was also uttered in initiation rituals, meaning "the law has and end, it can be left behind" (COMAROFF \& COMAROFF 1991: 128).

70. SCHAPERA (1988: 158) relates the case of two women who lodged cases against their polygamous husbands.

71. (Educated) women were initially, albeit gradually allowed to hold jobs within their own areas. Some also accompanied their husbands to other stations where they were able to take up employment beside their husbands (See testimony of Mme MmaSegaise who followed her husband to his mission posting during the colonial period, in MAFELA 1993).

72. Women serve in the Village Development Committees and in the District and Regional councils, and in other structures to which they belong as waged workers. 73. See also KALABAMU $(2004,2005,2006)$ for discussions relating to women's experiences with regard to issues of housing, land holding and inheritance in the postcolonial context.

74. See also GRIFFITHS $(1986,1996,1997,2004)$ for detailed discussions of various aspects of Tswana women's socio-legal experiences, and struggles with the legal pluralism of the Tswana legal terrain. The continuing influence of residual customary laws and practices also confounds Batswana women's socio-legal status.

\section{ABSTRACTS}

Historically, Batswana women's socio-legal position has been prescribed and proscribed by a myriad of patriarchal restrictions, comprising laws, rules and social sanction. The status and position of Batswana women was largely influenced and shaped by their relative position in Tswana traditional society. This position revolved around and reflected their perpetual minor position, as defined by customary/traditional law. Women's access to critical resources was therefore predicated upon their position as defined and strictly regulated by customary law and in the colonial period, by a combination of customary law and common law. Colonial education prepared men and women for different roles in the political economy, in conformity with Victorian ideals, which under-girded colonial state ideology. This necessitated the re-ordering of the Tswana productive and social relations, to align them more closely to the needs of the colonial state. Colonial education was however, mediated and was compelled to be responsive to the needs of Batswana, and their interpretation of it. Bechuanaland Protectorate was peripherally integrated into the South Africa economy, and essentially served as a labour reserve within the wider South African political economy. As an imperial buffer, Bechuanaland Protectorate remained severely underdeveloped, as Batswana became increasingly drawn to the 
South African labour market throughout the colonial period. This paper argues that in the process, education and migration transformed, reshaped and reorganised productive and social relations, as how this turn, (re)shaped women's socio-legal status.

Les femmes batswana et le droit. Société, éducation et migration (1840-1980). - Traditionnellement, la position socio-juridique des femmes batswana a été prescrite et proscrite par une multitude de restrictions comprenant des lois, des règlements et des sanctions sociales. Le statut et la position de ces femmes ont été influencéset modelés en grande partie par leur position dans la société traditionnelle tswana. Cette position reflétait la place inférieure qu'elles occupaient telle qu'elle était définie dans le droit coutumier/traditionnel. L'accès des femmes aux ressources était donc dicté par leur position telle qu'elle était définie et strictement régulée par le droit coutumier et, aprèsla période coloniale, par une combinaison de droit coutumier et de common law. L'éducation coloniale préparait les hommes et les femmes à différents rôles dans l'économie politique, conformément aux idéaux victoriens qui inspiraient l'idéologie coloniale d'État. Cela nécessitait la réorganisation des relations productives et sociales des Tswana pour les rapprocher des besoins de l'État colonial. Toutefois, l'éducation coloniale devait répondre aux besoins des Batswana et à leur interprétation de celle-ci. Le Protectorat de Bechuanaland resta très sousdéveloppé dans la mesure où les Batswana se trouvèrent de plus en plus absorbés par le marché du travail sud-africain pendant toute la période coloniale. Cet article avance qu'au cours de ce processus, l'éducation et la migration ont transformé, remodelé et réorganisé les relations sociales et productives et, ce faisant, redéfini le statut socio-juridique des femmes.

\section{INDEX}

Keywords: education, migration, law, gender, Botswana, Batswana, migration history, women and law

Mots-clés: droit, genre, histoire de la migration, femmes et droit

\section{AUTHOR}

\section{LILY MAFELA}

Department of Languages and Social Sciences, University of Botswana, Gaborone. 